Revue Française de Civilisation Britannique

\title{
Review of The British Growth Crisis.
}

\section{Clémence Fourton}

\section{(2) OpenEdition \\ Journals}

Electronic version

URL: https://journals.openedition.org/rfcb/1112

DOI: $10.4000 /$ rfcb. 1112

ISSN: 2429-4373

Publisher

CRECIB - Centre de recherche et d'études en civilisation britannique

\section{Electronic reference}

Clémence Fourton, "Review of The British Growth Crisis.", Revue Française de Civilisation Britannique [Online], XXI-2 | 2016, Online since 05 October 2016, connection on 04 March 2022. URL: http:// journals.openedition.org/rfcb/1112 ; DOI: https://doi.org/10.4000/rfcb.1112

This text was automatically generated on 4 March 2022.

\section{(c) $(1) \odot$}

Revue française de civilisation britannique est mis à disposition selon les termes de la licence Creative Commons Attribution - Pas d'Utilisation Commerciale - Pas de Modification 4.0 International. 


\title{
Review of The British Growth Crisis.
}

\author{
Clémence Fourton
}

\section{REFERENCES}

Green Jeremy, Hay C., Taylor-Gooby P. (eds), The British Growth Crisis, Basingstoke, Palgrave Macmillan, 2015

1 The British Growth Crisis, edited by Jeremy Green, Colin Hay, and Peter Taylor-Gooby, investigates the socio-economic features of the growth model of the British economy since 1979, whose structural flaws were revealed by the 2008 crisis. The study is predicated upon the idea that the perception and presentation of the crisis condition the response of policy-makers, whose decisions crucially impact the socio-economic order. Besides this constructivist view of the crisis, the contributions share the diagnosis that the crisis has been wrongly interpreted as a crisis of debt rather than as a crisis of growth. As a result, the crisis response has not tackled the fundamental short-comings of the British economy. Their paradigm is resolutely Keynesian; they favour public investment over austerity, and generally advocate a social market economy.

2 In the growth model that led to the 2008 crisis, finance is paramount. The financialization of the British economy started with the end of the Bretton Woods system in 1971 and went full-scale in the years following the election of Margaret Thatcher. Through a review of various macroeconomic indicators, Graham Gudgin and Ken Coutts demonstrate that the market economy reforms implemented after 1979 did not better British economic performances (Chapter 1). Craig Berry argues that the development of the financial sector was pursued at the expense of the rest of the economy, and in particular of the industrial sector, which accounts for the quantitative and qualitative disequilibrium of the British trade balance - the United Kingdom (UK) mainly exports services and largely relies on imports even for every-day consumption goods. This has deleterious social effects, as the service industry mainly offers lowskilled, low-waged jobs and few apprenticeship opportunities (Chapter 7). 
Financialization occurred hand in hand with deregulation throughout the 1980s. Jeremy Green quotes the 1986 Big Bang introduced by Thatcher as a crucial moment since it created bonuses for traders by removing the cap on transaction fees. This led to an explosion of income inequalities, strikingly illustrated by the indicator which has been publicized by the Occupy Wall Street movement: the income share of the richest $1 \%$ of the UK population, who are mostly financial workers, rose from c. $6 \%$ in 1979 to c. 15\% in 2007 (Chapter 3).

But the main political response to the 2008 crisis did not focus on the financial sector, whose unsustainable predominance had just been demonstrated at the cost of a whole year's worth of Gross domestic product (GDP): it consisted in cutting public expenditure (Chapter 6). In 2010, David Cameron established immediate and stark deficit reduction as an economic imperative. Ben Clift identifies the macroeconomic rationale behind the austerity programme of the Coalition. Fiscal consolidation was thought necessary to guarantee Britain's economic stability and credibility -translating into low interest rates- and reduction of public expenditure would not affect growth. The initial bail-out and stimulus (2008-2010) was in keeping with what other main economies were doing and so was the austerity programme implemented from 2010. But by 2012, Britain's ongoing austerity therapy was deemed too severe and too quick even by the International Monetary Fund. Its research unit, led by Olivier Blanchard, reconsidered its theory on multipliers, stating that public expenditure, in times of crisis, might be more strongly correlated with growth than was initially assumed and therefore that austerity was likely to undermine recovery. ${ }^{1}$

4 The Coalition's deficit reduction scheme was indeed overwhelmingly based on public spending cuts with $80 \%$ rather than on taxation, $20 \%$, (p. 168) and was implemented at all levels of government, thus also taking the form of localism (Chapter 8). Decentralization, which is in itself politically neutral, is analysed by Danny MacKinnon, Andrew Cumbers and David Featherstone as one of the key features of neo-liberal reforms in the UK, as it makes for a convenient mixture of local empowerment rhetoric, power centralization and blame avoidance for unpopular budget cuts. Daniela Tepe-Belfrage's gendered analysis of both policy and rhetoric surrounding the Coalition's Politics of Community underlines that this localism was presented as a community response (the Big Society) to a social problem (Broken Britain), thus reducing poverty to individual problems and evacuating structural socio-economic factors. Moreover, the criminalization of the poorest in Britain, which has grown jointly with welfare retrenchment ${ }^{2}$ has, especially in the wake of the 2011 riots, promoted conservative gender norms, constructed marriage as the utmost moral norm and infantilized single mothers (Chapter 12). Generally speaking, the authors of the volume agree that the political response to the crisis has not addressed the structural problems and weaknesses of the British socio-economic situation - share of the financial sector, qualitative aspect of employment, inequalities - and have, on the contrary, contributed to reinforcing them.

5 The alternative socio-democratic model of growth that they advocate has to comply with a number of criteria, which Peter Taylor-Gooby qualifies as a "Left Trilemma" ( $\mathrm{p}$. 126): the (socio-democratic) Left has to uphold policies which are deemed credible by mainstream economic actors, appeal to voters, and guarantee some form of redistribution (Chapter 5). The question of labour regulation is a good illustration of such an attempt to accommodate both capital and labour (Chapter 9). Jason Heyes and 
Paul Lewis conclude that protective legislation on dismissals cannot be said to have a negative effect on (un)employment rates. Frank Pyke takes this conclusion one step further, arguing that employment protection should be placed at the heart of the growth model (Chapter 13). He argues that the idea that social improvements follow growth (in the form of trickle-down effects) is fundamentally flawed: improved social conditions, both inside and outside work, are more likely to favour productivity than for example, highly unregulated working times imposed on employees. This argument applies to the whole British economy (Chapter 11). Andrew Tylecote and Paulina Ramirez indeed argue that the domination of the financial sector over industry undermines innovation (because executive boards are fund managers rather than investors) and productivity (because employees are not part of strategic decisionmaking).

6 The growth model proposed by the authors is also more democratic. Gerry Stoker argues that policy can be planned with the long-term in mind, and not just to satisfy immediate political goals (Chapter 4). Similarly, localism can be implemented in a way that does not bypass local representative bodies, and actually contributes to empower local communities, thus reinforcing the democratic network (Chapter 8).

All in all, this book offers a comprehensive review of the economic and social effects of the politics of growth that had been implemented in the UK before 2008 and since then. The authors see the crisis as a missed occasion for reform. Not only has it not triggered any change of political and economic paradigm, but the response to the crisis has even further embedded the structural flaws of the British liberal capitalist economy. If it does present a substantial programme of social market reforms, the book does not question the existence of capitalism itself. The authors also make various uses of "neoliberalism" as an analytical category, which tends to insist on the transnational and ideological dimensions of the contemporary capitalist system and its latest crisis. ${ }^{3}$ They rather focus on the intrinsic workings of the British economic system and, through multi-scalar and historicized analyses, reassert the political nature of macroeconomics. The ambivalence of the notion of "model" pervades the book, designating both the successive institutional and political changes which have shaped a problematic system and the normative propositions of a reformist agenda. As such, the volume is a useful and well-documented tool for anyone willing to question the contemporary politico-economic order.

\section{NOTES}

1. IMF, World Economic Outlook: Growth Restructuring, Dangers Remain, Washington, IMF, October 2010.

2. Daniela Tepe-Belfrage's analysis draws on the work of Loïc Wacquant, who showed that one of the neoliberalevolution of the American state was that the reduction of social support was paralleled by development of a repressive apparatus targeting the poor. See WACQUANT Loïc, Punishing the Poor. The Neoliberal Government of Social Insecurity, Durham, NC, Duke University Press, 2009. 
3. MIROWSKI Philip, Never Let a Serious Crisis Go to Waste: How Neoliberalism Survived the Financial Meltdown, London and New York, Verso, 2013.

\section{AUTHORS}

\section{CLÉMENCE FOURTON}

Laboratoire MIMMOC, Université de Poitiers

Clémence Fourton est agrégée d'anglais. Ancienne élève de l'ENS de Lyon, elle a enseigné trois ans à l'Université de Cambridge. Elle prépare actuellement une thèse sur les effets sociaux de la crise de 2008 au Royaume-Uni, sous la direction de Susan Finding 